\title{
Majlis Ta'lim: Institution for Strengthening Islamic Moderation
}

\author{
Muh. Hafidz \\ LAIN Salatiga \\ muh.hafidz@iainsalatiga.ac.id
}

\begin{abstract}
This article aims at answering the questions on how the strategy used by majlis ta'lim developed in the Nahdliyyin community in strengthening Islamic moderation in this globalization era, and what are its advantages as non-formal institution. In term of answering these questions, the writer used technique of collecting the data through interview and observation. Considering that this study tends to be traditional, there is no need written documents. The interview was conducted with the Muslim figures as activists of majlis ta'lim, and the observation was carried out through joining the recitation held by Muslimat. The collected data show that majlis ta'lim is a strategic place for strengthening and building Islamic moderation. Its strategy is carried out through several ways. First, inviting Islamic moderation figures to majlis ta'lim. Second, determining moderate themes as the main focus of the recitation. Third, optimizing majlis ta'lim as a massive movement. The advantages of majlis ta'lim as one of public forums for Muslim community are: First, majlis ta'lim is a forum for education and teaching followed by its members. Second, the emotional relation among those members is stronger as compared to those in other forums. Third, the recitation in majlis ta'lim makes no difference of profession, occupation and position of the members.
\end{abstract}

Keywords: majlis ta'lim; institution; Islamic moderation.

\begin{abstract}
Abstrak
Artikel ini bertujuan untuk menjawab pertanyaan tentang bagaimana strategi yang digunakan majelis ta'lim yang berkembang di komunitas Nahdliyyin dalam memperkuat moderasi Islam di era globalisasi ini, dan apa keunggulannya sebagai lembaga nonformal. Untuk menjawab pertanyaan-pertanyaan tersebut, penulis menggunakan teknik pengumpulan data melalui wawancara dan observasi. Mengingat kajian ini cenderung tradisional, maka tidak diperlukan dokumen tertulis.
\end{abstract}


Wawancara dilakukan dengan tokoh-tokoh muslim selaku penggiat majlis ta'lim, dan observasi dilakukan dengan mengikuti pengajian yang diselenggarakan oleh Muslimat. Data yang terkumpul menunjukkan bahwa majelis ta'lim merupakan tempat yang strategis untuk memperkuat dan membangun moderasi Islam. Strateginya dilakukan melalui beberapa cara; Pertama, mengundang tokoh-tokoh moderasi Islam ke majlis ta'lim; Kedua, menentukan tema moderat sebagai fokus utama pengajian; Ketiga, mengoptimalkan majlis ta'lim sebagai gerakan masif. Keunggulan majlis ta'lim sebagai salah satu forum publik bagi umat Islam adalah; Pertama, majlis ta'lim merupakan wadah pendidikan dan pengajaran yang diikuti oleh anggotanya; Kedua, hubungan emosional antara anggota tersebut lebih kuat dibandingkan dengan forum lainnya; Ketiga, mengaji di majlis ta'lim tidak membedakan profesi, pekerjaan dan jabatan anggotanya.

Kata Kunci: majlis ta'lim; lembaga; Moderasi Islam.

\section{INTRODUCTION}

Islamic educational institution in Indonesia is now dealt with considerable challenges in this globalization era. It includes both formal and nonformal educational institutions. The formal institution includes Islamic schools and madrasa under the authority of the Ministry of Religious Affairs or the Ministry of Education. Non-formal educational institution includes majlis ta'lim, majlis istighosah, majlis mujahadah and the like. The severe challenges faced by these educational institutions are the impacts of development and globalization. Those challenges are manifested in the form of the emergence of transnational Islamic understanding with transnational ideology that massively reaches Indonesia, as the effect of world globalization.

According to Husni (2018: 46) the challenges faced by Muslims, including majlis ta'lim developed in the Muslim society are considered so hard. Those challenges are derived from two main sources. First, the emergence of transnational movements in Indonesian territory. Second, the support for transnational Islam to Indonesia in the form of qualified human resources.

Transnational Islam is a new Islamic movement believed to be different from the one previously existed. This is in line with Suharto's 
JNUS: Journal of Nahdlatul Ulama Studies, Vol. 1, No. 2, Juli 2020: 162-180

opinion (2017: 158) that this movement is an Islamic religious movement which has an international network, its emergence brings a new religious understanding and ideology which is different from the local concept.

This kind of movement is not solely different from the previous Islamic movement; more than that, it is terribly trying to eliminate the understanding of Islam in Indonesia. This is definitely proven by its radical nature, without any compromise towards Islam in Indonesia. Transnational Islamic radicalism derives from the countries which tend to be radical and not contextual in Indonesia. This form of religious radicalism is as follows (Fitriani, 2015: 122). First, it is transactional, meaning that this understanding originates mostly from countries in the Middle East. Second, the main target of this movement is young generation conducted through educational activities at schools, colleges, and places of worship (mosques, surau, and musholla). To achieve the target, this movement holds various activities such as seminars, regular learning, radio broadcasts, bulletins, the establishment of Islamic boarding schools and formal educational institutions.

Considering that the target of this radical movement is young generation in some educational institutions, the society should immediately and wisely respond to this matter. Young generation is an asset for the nation, the holder of this nation's leadership continuity, the future generation. If the prospective holder of future generations have been exposed to hardline ideology, it will certainly threaten the existence of moderate Muslims in Indonesia as well as the existence of our nation and state.

The emergence of transnational Islamic doctrine is accompanied with the efforts to affect Indonesian Muslims. The method of instilling the understanding and influence for Indonesian Muslims is carried out by founding educational institutions. Many of those are affiliated with the understanding of transnational Islam. In this context, private educational institutions frequently become the agents of an ideology of an organization or its main foundation (Suharto, 2015: 87). In addition to establishing Islamic educational institutions, they use all methods 
considered effective. The salafi movement applies various approaches including personal approache and open propaganda on the pulpit which is then continued with interactive dialogue. Besides, they also publish some books, newsletters and magazines that are distributed for free to the wider community. Building television and radio stations in some regions is considered strategic (Husni, 2018: 56).

The emergence of transnational doctrines has implication towards the dynamics of Indonesian Muslim thought. It leads to the emergence of two extreme groups among those Muslims. According to Zamimah (2018: 78) the two Muslim groups in question are right and left extremes which contradict each other. These groups tend to be extreme and strict in understanding and implementing Islamic teachings. It is indicated by the tendency to impose their will in the community with bad manners. These have caused fidgetiness and noise in Indonesian. The second group, the left extreme tends to be aware of understanding the teachings of Islam, sometimes performing irrational act excessively.

The situation of Muslim and non-Muslim in Indonesian is absolutely safe when there is no coercion of the will of certain groups with impolite action. This is the thing that leads to noise in public space. Moreover, when religion is opposed to the state, they ask question on the basis of the state, whereas this problem has never existed before. The basis of the state is questioned like a nation which has just been born or the state which is free from the colonialism and is still searching for its basis.

Ideally, educational institutions organized by Indonesian Muslims are able to promote Islamic moderation (Arifin, 2014: 416) to their people, including majlis ta'lim. It is a non-formal educational institution organized independently by the community. It exists in every level of society, both lower and upper society, rural and urban community. This institution can be accessed by all members of the community. Therefore, it is necessary to study on how the strategy used by majlis ta'lim in strengthening Islamic moderation for its members and what are the advantages of it. Khalif Muammar (2006: 293-300), states that the efforts 
to stop the liberal understanding as well as radicalism are strengthening the Islamic worldview and mastering Islamic scientific traditions, avoiding dichotomy, and conducting wasathiyyaah approach.

\section{METHODOLOGY}

In term of answering these questions, the writer conducted interview and observation as techniques of collecting the data. The writer conducted interview with majlis ta'lim activists as well as the boards of Muslimat at Pabelan sub-district. Observation was carried out by attending the Muslimat recitation at the sub-district and branch level in the village of Pabelan.

\section{DISCUSSION}

\section{Majlis Ta'lim}

Majlis ta'lim is derived from Arabic language; it is a familiar term for Indonesian Muslim. Majlis comes from the word jalasa which means "sitting" and majlis means "seat". In other word, majlis means a place to sit together.

Ta'lim is a noun made from a verb "allama" which means "teaching or transferring knowledge". More comprehensively, majlis ta'lim can be interpreted as a place to sit together in a forum to teach, give and transfer knowledge.

In Indonesia's educational context, majlis ta'lim is defined as a nonformal educational institution utilized as a place to teach religious knowledge to its jemaah. The jemaah are the members of the Islamic community coming from the various walks of life. They have strong emotional relationship among others.

According to Hasbullah (1995: 202) majlis ta'lim is an institution to implement Islamic education and teaching. This definition is in line with the one stated by Asrohah (1999: 50), he asserts that majlis ta'lim is a nonformal educational institution used as a media for implementing Islamic education and teaching. In other word, it is a media to improve the knowledge and understanding of Islam for internal Muslims. 
As an educational institution, it plays an important role as a media to propagate and promote the teachings of Islam to society. Effendy Zarkasy in Muhsin (2009: 1) asserts that majlis ta'lim is interpreted not only as a part of da'wah method but also as a learning forum to achieve the ideal Islamic religious knowledge in which every Muslim needs it.

This institution has its own concept, which is different from other non-formal educational institutions. Its members are usually permanent as the participants of the recitation just like at a formal school. They are local residents where majlis ta'lim is established, and they can freely manage its concept based on their style of thinking.

According to Abdul Jamil et al (2012: 23), majlis ta'lim has functions as follows: First, as a place for teaching and learning activities, second, as education and skill institution, third, as a place for conducting some activities and creativity, fourth, as a center for coaching and development, and fifth, as a communication network and a place for friendship.

As a non-formal educational institution, it has weaknesses and strengths, yet it does not have magnificent building as owned by pesantren, madrasa, schools and universities. It has some advantages as compared to other educational institutions. Tahqiq (2011: 50) explains that one of the advantages of majlis ta'lim is as a media to propagate and promote Islam. It teaches its member some issues related to Islam theoretically and practically which include; First, the issue of proper worship as an effort to get close to Allah and another real issue in religious life comprehensively. Second, respecting teachers manifested in the form of tawadhu', kissing hands and ta'dhim. Third, the teaching to implement noble morality properly in daily life, such as how to dress according to condition and place and how to talk and communicate with others politely. Fourth, majlis ta'lim plays a role as a source of solution to the problem of religion and life. This shows that majlis ta'lim focuses more on the issues of applicable worship to its members. Besides, it also emphasizes on the issue of morality.

In general, the list of agenda commonly held in majlis ta'lim event comprises of some steps: First, opening, it is done by reciting Surah Al- 
Fatikhah. Second, reciting sholawat in the form of al barjanji. Third, reciting surah yasin and asmaul husna, continued with Tahlil. Fourth, tausiyah by the speaker. Fifth, closing and prayer. The list of agenda held in majlis ta'lim is almost the same as those throughout Indonesia, especially in Java Island. As a comparison, it can be seen the composition of majlis ta'lim event in Jakarta area as written by Tahqiq (2015: 60). The sequence of events in the recitation is as follows: first, tawassul (tadzarru', petition), second, sholawat recitation, third, reciting surah yasin, fourth, reciting dhikir, tahlil, tahmid, fifth, reciting ratîb al-haddâd (collection and arrangement of prayers compiled by al haddâd), sixth, reciting Asmâ 'alHusna, seventh, Maulid Nabi, eighth, taushiyyah, ninth, and closing prayer.

More specifically, Tahqiq (2011: 49) explains that majlis ta'lim is the right media to teach Islam peacefully and comprehensively. Its existence and role can be increased amid today's millennial society, as previously conducted by the da'wah actors in the early days of Islam. As a result, Indonesian society accepts Islam peacefully, politely, far from violence. The Islamic da'wah actors in the early period of Islam are tarekat teachers, Sufis, traders, preachers, not military commanders.

Majlis ta'lim is a da'wah medium of moderate Islam which is comprehensive in accordance with the expectation of its jemaah. It is a meeting forum of cultures from various tribes. According to Suharto (2017: 158) trade, marriages, and culture as well as Sufistic elements are an effective way for the Indonesia Islamization, so Indonesian Islam becomes a moderate face which is different from the face of Islam elsewhere.

\section{Islamic Moderation}

Islamic moderation is derived from the terms Islamic and moderation. Moderation means not excessive attitude (Enchols and Sadzily, 2007: 478). Islam as a religious teaching brought by Muhammad for all mankind is a moderate religion in various aspects.

In the English dictionary (Minor: 1994, 798) the word moderation is interpreted as average in amount, intensity, quality etc., not extreme of 
having opinions that are not extreme and keeping or kept within limits that are not excessive. There are three definitions stated on the dictionary above, namely the average, not extreme understanding and not excessive.

Islamic moderation is similar to al-Wasathiyah. It is from Arabic language, namely "wasath" which means "amid" (Warson, 1997: 1662) or is interpreted between two sides (baina al tarfain) (Ma'luf, 1986: 900).

Wasath has some meanings; first, as something that is in the middle, between two or more sides, second, the situation of the most important thing, good, fair and qualified. It is between two opposing sides which are contradictory, one side is despicable and the other is good (Yabi et al, 2014: 137).

According to Al Qardhawi (2007: 26-31) wasatiyah has six meanings. First, justice, because justice is a requirement for receiving a witness' testimony. Second, a straight path, far from inclinations and deviations. Third, goodness, because goodness is in the middle, both material and immaterial things. Fourth, safety, far from threatening danger compared to the side of edge. Fifth, showing the strength, and seventh, showing the unity.

Al Qardhawi (2007: 23-24) asserts that wasatiyah is the middle and balance between two opposing sides, where the one does not have influence on the other side, or in other word it ignores the other one, and one does not take more rights, or endangers the other. The two opposing sides explain about God and humanity, spiritual and material, hereafter and the world, revelation and reason, past and future, individual and reason, reality and ideal, rights and obligations, statutes and changes, texts and ijtihad, texts and goals, traditions and reason and the like.

Hanafi (2013: 3-4) defines moderate (al-wasat) as a method of thinking, interacting and behaving in tawâzun (balanced) in addressing two conditions, so that attitudes are found in accordance with Islamic principles and traditions, which is balanced in attitudes, worship and morals.

Ahmad Umar Hashim's opinoin, as quoted by Shihab (2019: 39) defines wasatiyah as balance and equality between the two ends so that 
JNUS: Journal of Nahdlatul Ulama Studies, Vol. 1, No. 2, Juli 2020: 162-180

one of them does not interfere the other one, there is no excess and no deficiency, no transgressions and no reduction of limit, following the most important and perfect.

Islamic moderation is an inherent character in the Islamic teachings, because the substance of Islamic moderation is the teachings of Islam itself which is good and fair (Baihaqi, 2018: 211).

The moderate Muslim movement is one of the best options for grounding tolerance. It is a strong basis of contemporary text, tradition and reality. Its character to reject violence, radicalism and terrorism, proves that the concept of moderate Muslim is closest to the Qur'an (Syukur, 2012: 98).

In more detail, Al-Qardhawi (1998: 48) explains the characteristics of the moderation attitude that include: First, the middle attitude among the groups that invite those whose practice has narrow mazhab of thought with those groups inviting their Jemaah to be absolutely free from mazhab. Second, the middle attitude among groups that depend the law solely on the reason even though it deviates from qat'i text, with groups that deny the role of reason even though it's just for understanding the text. Third, the middle attitude among the groups that have hard and strict behaviour in matters of Furu' 'with the groups who behave easily even in matters of ushul. Fourth, the middle attitude among the groups that overglorify the turath though it has changed with the group that ignores it even though there is a useful guide in it. Fifth, the middle attitude among the groups that deny the role of inspiration absolutely with the group that receives it excessively and make it as the source of syara law. Sixth, middle attitude among the groups that are excessive in forbidding, as if there is not a halal case with a group that easily justifies as if nothing is forbidden. Seventh, middle attitude among groups that ignore the texts with the reason to keep the maqashid syariah with those that ignore it with the reason to protect the texts.

According to Qardhawi, the aspects of moderation include aqeedah, worship, morality and the establishment of Islamic law (2007: 33-40, Ramadan, 2018: 33, Yusuf, 2018: 40). Aqeedah aspects include: First, this 
is comparison between aqeedah which has absolute belief and the one that does not. Islam teaches us to trust in something with evidence and common sense. Second, trust between polytheism and atheism, Islam teaches us to believe in Allah. Third, the nature between reality and delusion. Islam explains that this nature is real, yet there is a deeper one, that is Allah who regulates it. Fourth, among humans who consider themselves as god and the ones that consider themselves as slaves. Islam explains that human is a given the task as a caliphate on earth. Fifth, among the groups that consider the prophet as a saint to the degree of god with a group that does not recognize and reject him, Islam teaches us to believe that prophet is a selected human. Sixth, a group of people who deify the mind, and those who deify revelation only (Qardhawi, 2018: 3335).

In the aspects of worship, Islam between two groups prioritizes the morals and goodness for humans and the groups that only worship to god without mingling with other people and merely enjoy the beauty of the world (Qardhawi, 2018: 35).

The moral aspect involves several matters: first, humans between the dimension of angel and animal. Second, Islam among the groups who consider it as motivation aspect that can enhance it by means of torturing it and the material aspects without any spirit and its motivation. Third, Islam among the groups that solely confess the world as the last life, and groups that only recognize the life of the hereafter as true life (Qardhawi, 2018: 36-38).

The aspects of Islamic law establishment involve, first, halal and haram, the Jew is too excessive in prohibiting something, while Christians legalize many things. Second, families with the limitation of wife in certain numbers and conditions. Third, peace and war. Fourth, individual and group (Qardhawi, 2018: 38-40).

Those are the aspects of Islamic moderation that need to be developed in line with the teaching of Islam itself. Islam concerns the issues of belief, worship, morality and muamalah, so Islamic moderation also concerns the matters mentioned above. 
The implementation of moderation concept varies according to the situation and conditions in which Muslims are located. The concept of moderation in Indonesia is certainly different from that in other countries. In comparison, the moderation concept developed in Malaysia includes several things. The concept of Islamic moderation consists of: 1) moderation on aspects of religious freedom; 2) moderation in the distribution of assets; 3) moderation in the distribution of political power; 4) moderation in the language use; and 5) moderation in education (Hanapi, 2014: 56-60).

In Indonesia context, Islamic moderation might refer to Ahmad Siddiq's point of view (2006: 63-68), he asserts that this principle of moderation must be maintained and developed as well as possible by the Ahl al-Sunnah wa al-Jamâ'ah in all aspects that include faith, sharî'ah, morals, inter-group relations, state life, culture, propaganda, etc.

\section{Majlis ta'lim: Media for Building Islamic Moderation}

Religious moderation is actually the key to creating tolerance and harmony, whether at local, national and global levels (Sutrisno, 2019: 330). Therefore, ideally religious moderation is not only the responsibility of government, but also all levels of society. Every level of society has a public space to meet, one of which is majlis ta'lim. It always grows and develops, regardless of the social strata.

Majlis ta'lim needs to improve optimally in accordance with the policies of social organization as an effort to promote Islamic moderation. Islamic moderation must always be available in the midst of society. Majlis ta'lim becomes a media to promote moderate Islamic values. The more intense Islamic moderation in the midst of society, the stronger the values of Islamic moderation.

Islamic moderation should always be available at every level of society as an effort to eliminate religious extremism that recently emerges in the midst of Indonesian people's lives. The emergence of Islamic moderation, in public terms, indirectly narrows extremity space in religion. 
Conversely, if extremities exist on one extreme side of life, and religious moderation is absent, religious intolerance and conflict become "ember in chaff", which can explode, if ignited with a political axis (Sutrisno, 2019: 328).

With the strength of Islamic moderation, people will not easily accept radicalism doctrine, extremism and terrorism movements. On the contrary, they will be a strong fortress to prevent the movement of radicalism and terrorism as well as preventing religious siltation. Thus, religion as the guidance for human, cannot easily be accepted if its doctrine contains violence and cruelty (Faiqoh et al, 2018: 57). Majlis ta'lim will be more powerful and be able to prevent radicalism and terrorism, when managed properly by NU as a strong social organization.

In term of strengthening Islamic moderation, majlis taklim conducts some efforts. First, inviting moderate Islamic figures who have moderate Islamic views. It aims to deliver moderate Islamic teachings in the hope to enlighten the whole people, as stated by $\mathrm{R}$ as follows:

The speakers of the recitation held by Muslimat majlis ta'lim in the sub-district level are usually from NU itself. They are the ones who really understand about the teachings of Ablussunnah wal Jamaah and Islamic moderation. The scholars whose teachings lead to calm and cool situation and are easily accepted.

Many Muslim scholars are invited to deliver speech on the values of moderate Islam, the peaceful and friendly Islam. This speech aims to strengthen Islamic moderation, as stated by as follows:

In term of strengthening Islamic moderation, it could be carried out through mavidhah hasanah in every meeting both in Muslimat and fatayat activities. The recitation held at the village frequently invites NU board as the speaker, and sometimes local Muslim scholars. While at the sub-district level, the speakers are from the sub-district NU board or those from another city. 
JNUS: Journal of Nahdlatul Ulama Studies, Vol. 1, No. 2, Juli 2020: 162-180

This is the first strategy that majlis ta'lim undertakes in strengthening Islamic moderation. By inviting moderate Islamic figures, it will indirectly affect the audiences' insight and thought.

Second, strengthening moderate Islamic thought through mavidhah hasanah conveyed in the well-organized meeting. Moderate religious thought can be applied by referring to Islamic moderation thought. It can be broken down into applicable themes that can be presented in majlis ta'lim. These themes include, aswaja, the importance of reason dimension, avoiding takfir, the importance of mazhab, mujahadah and riyadlah, good morality, Islam and local culture, and Islam with modern culture and friendly dakwah. These themes of Islamic moderation are delivered through majlis ta'lim spread throughout the community. As said by $\mathrm{R}$, in her interview as follows:

The recitation conducted by Muslimat is the one that might bring a cool atmosphere for the whole community, not only nahdliyyin people but also all levels of society although the majority of rural communities in the Pabelan sub-district are loyal members of NU.

The themes of Islamic moderation have not yet been fully adopted as the main focus of the recitation in majlis ta'lim, but there has been a tendency to promote a peaceful Islam, an Islam that is rahmatan lil alamin. Sometimes there are some speakers who object to convey the themes related to Islamic moderation, as stated by RA as follows:

Just take the ordinary themes; never discuss hard topics related to Islamic moderation. We deliver the themes as usual recitation, invite and strengthen the faith, invite them to perform good deeds and prevent them from doing immoral acts.

Not all the themes of Islamic moderation developed are wellplanned and neatly-arranged, originating from the values of Aswaja NU. Thoes themes are responsive, responding to the contemporary issues booming around them. As said by US as follows:

Some speakers have frequently delivered speech on responsive Islamic moderation. It aims to respond to the issues being discussed in the community through recitation forum. Those issues of Islamic 
moderation arise not only from boards of the majlis ta'lim, but also from the Muslim priests as speakers.

The theme of Islamic moderation will be better when proposed by the committee. Those themes on Islamic moderation are neatly arranged in order to be better.

Third, shaping majlis ta'lim as a massive movement. The movement and socialization of religious understanding are usually started from the top to down. Starting from the public figures as the role model for their followers, from the king to his people. It is expected that lower society will absolutely imitate the understanding of their role models. This way was exemplified by Walisongo in the process of islamization in Java. Another method is carried out by means of intensive interaction among people through trade, marriage and other associations. This method can be applied in the process of understanding and strengthening Islamic moderation in the midst of Indonesian Muslim society at present.

The movement of moderation can be carried out massively through recitation in this majlis ta'lim. Almost all Muslim society in Indonesia has it, as a forum for religious teaching and learning. Majlis ta'lim in the villages was found varied in terms of their congregation, as stated by $R$ as follows:

There are 17 villages in Pabelan Sub-district. Each has Muslimat branch and Fatayat NU as well as majlis ta'lim. Each branch holds recitation in majlis ta'lim. On average, each majlis ta'lim is attended by approximately 75 to 200 people according to the number of residents. Meanwhile, the recitation of Muslimat NU in Pabelan District level which is held every Ahad wage is attended by around 2000 people.

The explanation above is reinforced by Lt as the deputy of Muslimat NU Pabelan Sub-district, she explained as follows:

All 17 villages in Pabelan Sub-district have active Muslimat branches, and the recitation held there is running well. The number of Muslimat recitation participants in Pabelan District is 
JNUS: Journal of Nahdlatul Ulama Studies, Vol. 1, No. 2, Juli 2020: 162-180

unpredictable for sure, but based on the amount of consumption provided, there are approximately 1,800 participants.

Based on these interviews it was found that each village has a majlis ta'lim under the coordination of the Muslimat branch and Fatayat NU. Each of them is attended by at least 50 people. If the congregation of this majlis ta'lim become the pioneer of Islamic moderation in their families and communities, then it is easy to shape a moderate Muslim society in Indonesia.

The number of participants attending the Muslimat recitation at the sub-district level is balanced and varied as in several sub-districts, as explained by RA, in her interview:

The Jemaah of Muslimat recitation in Bancak District is up and down depending on the bustle of the community. When they are busy with their own work in the rice fields, the number of participants is just around 700 people. On the contrary, when they have nothing to do, the participants might reach 1500 people even more.

Majlis ta'lim is not added yet with those managed by the community independently. The number could increase even more with the assumption that each hamlet in one village has its own majlis ta'lim. Based on the writer's experience found in his village, he encountered majlis ta'lim held on Saturday night, Tuesday night, and Friday night. Thus, the lower community is the main target of strengthening Islamic moderation in Indonesia. It is different from educational institutions and pesantren, whose scope is sometimes limited to students or santri. Majlis ta'lim spread in the community is a medium for strengthening Islamic moderation, and then it will be a massive movement as expected by the peaceful Indonesian Muslim.

This is the strategy carried out in majlis ta'lim for strengthening Islamic moderation. These three strategies should be carried out jointly among the boards, jemaah and the community. By doing so, the moderate community in all walks of life including in all public spaces will be a 
bastion of Islamic moderation as well as an effort to limit the space of radicalism movement.

Majlis ta'lim is the most strategic place to develop and promote Islamic moderation in the midst of society. It has strength as compared to other social forums. First, majlis ta'lim is a forum for education and teaching followed by its members directly. The lower society is the main target in strengthening the understanding of Islamic moderation. As said by Lt above, that the number of jemaah attendanig the recitation held by Muslimat NU Pabelan reached 2000 people. The presence of a large number of participants is a good start as the effort to strengthen Islamic moderation, and at the same time it could minimize the movement of religious extremism and radicalism.

If the understanding of Islamic moderation among the participants of majlis ta'lim is strong enough, it indirectly limits the opportunity for the development of religious radicalism movement.

Second, the emotional tie among the members of majlis ta'lim is stronger as compared to other forums. This is the starting point to strengthen and promote Islamic moderation in Indonesian. The recitation held regularly in majlis ta'lim will actually strengthen the understanding of its congregation and strengthen the emotional bond among them.

Third, the recitation in majlis ta'lim makes no difference of profession, occupation and position of its congregation. They are from many types of profession such as civil servant, teacher, trader and farmers. They attended the recitation together to promote moderate Islam. That is the urgency of majlis ta'lim as the effort to strengthen Islamic moderation in Indonesia.

Ideally, majlis ta'lim should be a massive movement for all walks of life in various regions. If all majlis ta'lim implement the importance of Islamic moderation at various levels and geographical areas, it will certainly have a great impact on strengthening Islamic moderation in Indonesia. 
JNUS: Journal of Nahdlatul Ulama Studies, Vol. 1, No. 2, Juli 2020: 162-180

\section{CONCLUSION}

Based on the discussion above, it can be concluded that the strategy used by majlis ta'lim in strengthening Islamic moderation includes several methods. First, inviting moderate Islamic figures to the majlis ta'lim. Second, strengthening moderate Islamic thought through mauidhah hasanah conveyed in the well-planned recitation. Third, shaping majlis ta'lim as a massive movement.

Majlis ta'lim as one of the public forums has several advantages. First, as a forum for education and teaching which is directly followed by its members. Second, the emotional bond among the members of majlis ta'lim is stronger as compared to those in other forums. Third, the recitation in majlis ta'lim makes no difference of profession, occupation and position of its members.

\section{REFERENCES}

Al Qardhawi, Yusuf, Figh al Wasatiyah al Islamiyah wa al Tajdid, Ma'alimu wa Manarat, (Beirut: Markaz Al Qardhawi li al Wasatiyah al Islamiyah wa al Tajdid, 2007.

Al Qardhawi, Yusuf, Mustaqbal al-Usuliyyah al-Islamiyah, Beirut: al-Maktab al-Islami, 1998.

Asrohah, Hanun, Sejarah Pendidikan Islam, Jakarta : Logos, 1999.

Baihaqi, Yusuf, Moderasi Dakwah Prophetic dalam Perspektif al Qur’ân, Jurnal Bimas Islam, Vol.11. No.I 2018.

Faiqah, Toni Fransiska, Radikalisme Islam vs Moderasi Islam : Upaya Membangun Wajah Islam Indonesia yang Damai, Al Fikra : Jurnal Ilmiah Keislaman, Vol. 17 no 1, Januari Juni 2018.

Fitriani, Laily, Pendidikan Peace Building di Pesantren, Upaya Pencegahan Radikalisasi, Ulul Albab, Volume 16, No.1 Tahun 2015.

John Echols dan Hasan Sadzily, Kamus Bahasa Inggris-Indonesia, Surabaya : Pustaka pelajar, 2007.

Muchlis M. Hanafi, Moderasi Islam: Menangkal Radikalisasi Berbasis Agama Jakarta: Ikatan Alumni al-Azhar dan Pusat Studi al-Qur'ân, 2013. 
Hanapi, Mohd Shukri, "The Wasatiyyah (Moderation) Concept in Islamic Epistemology: A case study of its implementation in Malaysia" Interntional Journal of Humanities and social science, Vol. 4, No. 9, 2014.

Hasbullah, Sejarah Pendidikan Islam di Indonesia, Jakarta : Rajawali, 1995.

Husni, Zainul Mu'ien, NU di Tengah Pusaran Ideologi-ideologi Transnasional, Jurnal Islam Nusantara, Vol. 02 No. 01, Januari - Juni 2018.

Jamil dkk., Abdul, Pedoman Majlis ta'lim, Jakarta : Dirjen Bimas Islam, Bagian Urusan Penerangan Islam, 2012.

Luis Ma'luf, Al Qamus Al Araby Al Alamy, Kairo : Al Maktabah Al Qahirah, 1986.

Muammar, Khalif, Atas Nama Kebenaran, Tanggapan Kritis Terhadap Wacana Islam Liberal, Kuala lumpur: Akademi Kajian Ketamadunan, 2006.

Muhsin MK, Majlis ta'lim, Petunjuk Praktis Pengelolaan dan Pembentukannya, Jakarta : Pustaka Intermasa, 2009.

Minor, William Chester, Oxford Advanced Learner's Dictionary, Oxford Univesity Press, 1994

Ramdhan, Tri Wahyudi, Dimensi Moderasi Islam, Al Insyiroh, Vol. 2, No. 12018.

Shiddiq, KH. Achmad, Khittah Nabdliyyah, Surabaya: Khalista-LTN NU Jawa Timur, 2006.

Shihab, M Quraish, Wasatiyah Wawasan Islam tentang Moderasi Beragama, Tangerang : Lentera Hati, 2019

Suharto, Toto, Indonesiasasi Islam, Penguatan Islam Moderat dalam Lembaga Pendidikan Islam di Indonesia, Al-Tahrir, Vol. 17, No. 1 Mei 2017 : 155-178.

Suharto, Toto, Gagasan Pendidikan Muhamadiyah dan NU sebagai Potret Pendidikan Islam Moderat di Indonesia, Islamica, Volume 9, Nomor 1, September 2015.

Syukur, Suparman, Islam Radikal VS Islam Rahmah, Teologia, Vol 23. No.1, Januari 2012.

Tahqiq, Nanang, Moderasi Gerakan Islam, Dialog vol 71, no 1, tahun xxxiv, Juli 2011. 
JNUS: Journal of Nahdlatul Ulama Studies, Vol. 1, No. 2, Juli 2020: 162-180

Warson, Ahmad, Kamus Al Munawwir, Surabaya : Pustaka Progressif, 1997.

Yabi, Shumsudin, Norhasnira Ibrahim, A.Irwan Santeri Doll Kawaid, Mafhum al Wasatiyah inda al Salafi as Salih, GJAT, Vol. 4 Issue 2, December 2014.

Yusuf, Achmad, moderasi Islam dalam dimensi Trilogi Islam (Aqidah, Syari'ah, dan Tasawuf), Al-Murabbi: Jurnal Pendidikan Agama Islam, Volume 3, Nomor 2, Juni 2018.

Zamimah, Iffati, Moderatisme Islam dalam Konteks Keindonesiaan, (Studi Penafsiran Islam Moderat M. Quraish Shihab), Al Fanar : Jurnal Ilmu Al Qur'an dan Tafsir, Volume 1, Nomor 1, Juli 2018.

Wawancara, RA, Pengurus Fatayat NU Kec Bancak, 4 Maret 2020

Wawancara, R, Pengurus Muslimat NU Kec Pabelan, 10 Maret 2020

Wawancara, Lt, Wakil Ketua Muslimat NU Kec Pabelan, Guru dan pendamping Camat Pabelan, 20 April 2020

Wawancara, US, Pengurus Muslimat NU Kec Pabelan, Pengurus Fatayat NU Kab. Semarang, 24 April 2020. 